\title{
MUC4 wt Allele
}

National Cancer Institute

\section{Source}

National Cancer Institute. MUC4 wt Allele. NCI Thesaurus. Code C128855.

Human MUC4 wild-type allele is located in the vicinity of 3q29 and is approximately $66 \mathrm{~kb}$ in length. This allele, which encodes mucin- 4 protein, plays a role in both cell adhesion and tumor progression. 